Review article

\title{
Evaluation of usage of bone scan index in assessment of metastatic prostate cancer
}

Halil Ćorović ${ }^{*}$, Nusret Salkica1 ${ }^{1}$, Safet Hadzimusic ${ }^{1}$, Enis Tinjak ${ }^{1}$, Adel Brčaninović ${ }^{2}$

${ }_{1}$ Clinic for Nuclear Medicine and Endocrinology, Clinical Center of Sarajevo University, Sarajevo, Bosnia and Herzegovina

${ }_{2}$ Clinic for Radiology and Nuclear Medicine of the University Clinical Center Tuzla, Tuzla, Bosnia and Herzegovina Corresponding author: Halil Ćorović, Clinic for Nuclear Medicine and Endocrinology, Clinical Center of Sarajevo University, Bolnička 25, 71000 Sarajevo, Bosnia and Herzegovina, email: halil.corovic@live.com

Received: 02.08.2021.

Accepted: 27.10.2021.

DOI: https://doi.org/10.48026/issn.26373297.2021.12.1.1

\begin{abstract}
Introduction: Prostate cancer has been the leading type of cancer to affect male population, and as such, it is a subject to efforts to furthermore diagnostic tools already in existence as well as development of new ones which will Aid early diagnostic, treatments as well as a follow up procedures and clinical trials. Bone scan index is a useful and objective biomarker used as a valuable tool for determination as to precise bone involvement in advanced cases, as well as a tool to predict the outcome in prostate cancer patients in clinical trials.

Methods: This paper is a non-experimental (qualitative) research, that is, a scientific review of the literature.

Results: The results we analyzed in this paper were collected from published academic journals.

Conclusion: As a new imaging biomarker, bone scan index has potential to predict therapeutic effects and survival of patients with prostate cancer. Using measurable diagnostic image parameters, the bone scan index is important for determining metastatic bone changes in prostate cancer patients.
\end{abstract}

Keywords: Bone scan index, cancer prostate, biomarkers

\section{Introduction}

Nearly 1.4 million people are diagnosed with cancer every year in the USA. Of these, half of patients suffer from a cancer that frequently metastasizes to bones (1). In fact, bones are the third most common site of metastatic malignancy after lungs and liver. Bone metastases can occur in just about any primary malignancy. The most common cancers to metastasize to bones are breast, prostate, thyroid, lung, and kidney cancer. In autopsy studies the incidence in breast and prostate cancers is as high as $73 \%(2)$.

Prostate cancer (PCa) is the most prevalent nondermatologic cancer in males. At presentation, $\sim 10 \%$ of patients have bone metastases, and almost all patients who die of prostate cancer have skeletal involvement (3). The clinical course of patients with metastatic prostate cancer can be relatively long, and several prognostic factors have been identified, including performance status, tumor grade, hemoglobin, serum lactate dehydrogenase, prostate-specific antigen, and alkaline phosphatase (4-6). It is the most common noncutaneous cancer, and the second most frequent cause of death from cancer among men in the USA. In Japan, 11,507 men were estimated to die of prostate cancer in 2014, making this disease the sixth leading cause of death from cancer (7). Prostate cancer is a bone tropic cancer, and nearly $85 \%$ of patients with fatal prostate cancer are reported to have bone metastases (8). Several studies have attempted to correlate the extent of skeletal metastatic involvement with survival in patients with advanced prostate cancer. A staging system based on distribution of bone metastases according to bone scintigraphy (axial versus appendicular) showed a significant association with survival (9). A different system based on the number of lesions identified by bone scintigraphy was also predictor of survival (10). However, although both systems were able to discriminate between patients at the extremes of their respective scales, neither was particularly effective at 
discriminating between patients toward the center of the range. Among the patients who die from $\mathrm{PCa}$, the incidence of skeletal involvement appears to be $>$ $85 \%(11,12)$. The standard treatment for patients with PCa with metastatic spread to the bones is androgen deprivation therapy (ADT); however, the vast majority of patients with PCa with bone spread finally become resistant to androgen deprivation and progress to castration-resistant PCa (CRPC) (13).

Early diagnosis of prostate cancer has increased since the introduction of the prostate-specific antigen (PSA) blood test $>25$ yr ago, but many patients still fail the initial treatment and progress to castration-resistant prostate cancer (14). One of the most challenging management tasks for researchers and pharmaceutical companies is to find new effective treatments for this aggressive stage of the disease, due to the potentially rapid development of metastasis where bone tissue is the most commonly affected $(15,16)$. After the development of metastatic castration-resistant prostate cancer (mCRPC), patients commonly initiate secondary hormonal manipulation or chemotherapy. At this stage, the therapeutic landscape has changed considerably since the introduction of new drugs in the last few years (17). These systemic treatments are not always well tolerated, and many patients soon acquire resistance; therefore, most of these patients need additional therapeutic options (18). In mCRPC patients, clinical or biologic parameters related to bone metastases have a major prognostic value (19). Bone scintigraphy (BS) is a widely used method for assessing metastatic spread to the skeleton, but there is still a lack of standardisation in its analysis. Interpretations of BS images are currently based mainly on a traditional visual analysis that is both subjective and interpreter dependent (20).

For monitoring progression of bone metastases on prostate cancer patients, serum prostate-specific antigen (PSA) is widely used as a biomarker in prostate cancer. Although prostate cancer can become refractory (castration-resistant prostate cancer), serum PSA provides limited information related to bone metastases. At present, PSA level has been considered an essential and practical marker for management of patients with PCa, but an elevated PSA level itself cannot always determine whether the region of bone, lymph nodes or visceral organ is metastatic spread or local recurrence. In addition, although PSA is the best marker for PCa monitoring, it is not PSA that represents or reflects the comprehensive status of $\mathrm{PCa}$ aggressiveness.
Considering the bone as the most prevalent site of metastatic spread in $\mathrm{PCa}$, we think that a more detailed approach to analysing bone metastasis would contribute to improvements in prognosis and even confer a survival benefit on the affected patients (13). Prostate cancer has a high risk of spreading metastases to the bone. An autopsy study of 1589 patients showed that $90 \%$ of prostate cancer patients aged 40 years or older had bone metastases (21). The bone metastases of prostate cancer are most often characterized as extended osteoblastic lesions radiographically. Although management of the bone metastases is making progress, advanced diseases with bone metastases remain incurable. In the cases of bone metastases there are risks of pathological skeletal fracture, intractable bone pain, and spinalcord compression during the clinical course (22). The most common form of metastasis from prostate carcinoma is on the bones, which occurs in about $80 \%$ of terminal prostate carcinoma patients. The median survival of prostate cancer patients with bone metastasis is $2-3$ years and the 5 -year probability of survival is $30 \%$. The mortality rate of patients with bone metastasis on the first medical examination is expected to be $90 \%$ after 10 years. Therefore, the prognostic prediction of prostate carcinoma by bone scintigraphy may be vital. However, the optimal method for detecting, quantifying, and grading tumor metastasis of bones is difficult. There were several attempts to quantify bone metastasis by bone scintigraphy, with different results $(23,24)$. The use of extent of disease (EOD) grade is useful for the prognostic prediction of prostate carcinoma. However, this method is subjective, and interobserver variation can be substantial (25).

Bone metabolic markers are useful to evaluate the activity but not the extent of bone metastases. Bone scintigraphy has been used as a primary imaging procedure for evaluating extent of bone metastases of the whole body in the case of an elevated serum PSA after diagnosis of prostate cancer. The extent of disease (EOD) on initial bone scintigraphy was used to stratify patients with prostate cancer (26). In addition, a computer-aided diagnosis system on bone scintigraphy images has been developed for improving the interpretations of bone scan images, which can help with understanding the spread of bone metastases. The system can indicate "Bone Scan Index (BSI)" which provides a quantitative measure of the percentage of the adult skeleton involved by bone metastases. Although it has been difficult to monitor therapeutic responses with bone 
metastases radiologically, BSI has potential to predict therapeutic effects and survival of patients with prostate cancer as a new imaging biomarker. However, few papers have yet to show the relationship between BSI and bone metabolic markers (27).

Bone scintigraphy is a very common examination for patients with prostate cancer to verify or exclude suspected metastatic disease. For patients with bone metastases the extent of the tumor burden is associated with survival $(28,29)$. The Bone Scan Index (BSI) was developed in order to quantify the amount of metastases in bone scans (30). BSI measures the tumor burden in bones as a percentage of the total skeletal mass and has been shown to be associated with survival of patients with prostate cancer (31). Automated BSI methods (32) have been developed to further increase the objectivity and clinical use of bone scans for patients with prostate cancer. Recent work has shown that the total BSI value and BSI change between bone scans are prognostic indicators and can be used as an imaging biomarker for prostate cancer patients (33-35).

Bone scintigraphy, however, is commonly used to assess skeletal tumour burden in prostate cancer patients, both in clinical routine and in nearly every clinical trial. In order to extract as much clinical information as possible from the bone scans, the Bone Scan Index (BSI) was developed as a quantitative tool to improve the interpretability and clinical relevance of the bone scan. BSI is a method of expressing the tumor burden in the bones as a percentage of the total skeletal mass (36).

Bone scintigraphy was also successfully used for the determination of the extent of metastatic bone disease that has shown to correlate with disease prognosis and proved to be a useful indicator of response to treatment (37-39).

An alternative approach to quantifying the progression of metastatic disease is to calculate a bone scan index (BSI) reflecting the burden on the skeleton. The tumor burden is expressed as a percentage of the total skeletal mass. This method was recently evaluated in patients with prostate cancer receiving chemotherapy, and the results showed that on-treatment change in BSI was closely associated with overall survival (40). The same study also showed that changes in PSA were not associated with survival, while adjusting for changes in BSI, indicating the value of BSI as a response indicator (41).

Visual image analysis for the detection of new lesions and the calculation of BSI is time consuming and subjective and involves inter-observer variability. We therefore recently presented an automated method for calculation of BSI (42). The method was designed to analyse one scan at a time, and it was shown that the automated method provides important clinical information comparable to that of visual BSI scoring (41).

BSI is calculated by first calculating the area of a hotspot classified as a metastatic lesion and then calculating the area of the corresponding skeletal region obtained from the segmentation of the skeleton (e.g. the skull or pelvis). Dividing the former by the latter and multiplying the result by a constant representing the weight fraction of the present skeletal region with respect to the weight of the total skeleton (43) gives an estimate of the volumetric fraction of the skeletal region occupied by the hotspot (41).

This method has now been further developed so that a comparison of two wholebody bone scans from the same patient is carried out automatically (41).

A template normal scan is used to establish correspondences between time points. As part of the method presented in a previous study, the template scan is warped to fit each individual scan using a nonrigid registration algorithm. Separate warps are used for anterior and posterior images (42). The aim of this study is to provide assessment as to involvement of bone scan index to diagnostic procedures and the gradation to which bone scan index is relevant for determination of the metastatic changes on bones in patients with advanced prostate cancer.

\section{Materials and methods}

This paper is a non-experimental (qualitative) research, that is, a scientific review of the literature. Upon creating the research, different databases were used, including Pub Med, Medline, using key words "bone scan index", "prostate cancer", "bone metastate", "scintigraphy". The research is limited to articles published in English. 
Results

Table 2. Variables are relative to the objective of the research

\begin{tabular}{|c|c|c|c|c|}
\hline Author & Study name & Aim & Research method & Results \\
\hline $\begin{array}{l}\text { Armstrong AJ, } \\
\text { Anand A, } \\
\text { Edenbrandt L, } \\
\text { Bondesson E, } \\
\text { Bjartell A, } \\
\text { Widmark A, et al } \\
(2018)\end{array}$ & $\begin{array}{l}\text { Phase } 3 \\
\text { Assessment of the } \\
\text { Automated Bone } \\
\text { Scan Index as a } \\
\text { Prognostic Imaging } \\
\text { Biomarker of } \\
\text { Overall Survival in } \\
\text { Men With } \\
\text { Metastatic } \\
\text { Castration- } \\
\text { Resistant Prostate } \\
\text { Cancer A } \\
\text { Secondary Analysis } \\
\text { of a Randomized } \\
\text { Clinical Trial. [44] }\end{array}$ & \begin{tabular}{|l|} 
To clinically assess \\
in a prospectively \\
defined analysis \\
plan of a clinical \\
trial the automated \\
Bone Scan Index \\
(aBSI) as an \\
independent \\
prognostic \\
determinant of \\
overall survival \\
(OS) in men with \\
metastatic \\
castration-resistant \\
prostate cancer \\
(mCRPC).
\end{tabular} & $\begin{array}{l}\text { This investigation was a prospectively planned } \\
\text { analysis of the aBSI in a phase } 3 \text { multicenter } \\
\text { randomized, double-blind, placebo-controlled clinical } \\
\text { trial of tasquinimod (10TASQ10). Men with bone } \\
\text { metastatic chemotherapy-naive CRPC were recruited } \\
\text { at } 241 \text { sites in } 37 \text { countries between March } 2011 \text { and } \\
\text { August } 2015 \text {. The statistical analysis plan to clinically } \\
\text { evaluate the aBSI was prospectively defined and } \\
\text { locked before unmasking of the 10TASQ10 study. } \\
\text { The analysis of aBSI was conducted between May 25, } \\
\text { 2016, and June 3, 2017. }\end{array}$ & $\begin{array}{l}\text { Of the total } 1245 \text { men enrolled, } 721 \text { were evaluable for the } \\
\text { aBSI. The mean (SD) age (available for } 719 \text { men) was } 70.6 \\
(8.0) \text { years (age range, } 47-90 \text { years). The aBSI population } \\
\text { was representative of the total study population based on } \\
\text { baseline characteristics. The aBSI (median, } 1.07 \text {; range, } 0 \text { - } \\
32.60) \text { was significantly associated with OS (hazard ratio } \\
\text { [HR], } 1.20 ; 95 \% \text { CI, } 1.14-1.26 ; \mathrm{P}<.001) \text {. The median OS } \\
\text { by aBSI quartile (lowest to highest) was } 34.7,27.3,21.7 \text {, } \\
\text { and } 13.3 \text { months, respectively. The discriminative ability of } \\
\text { the aBSI (C index, } 0.63 \text { ) in prognosticating OS was } \\
\text { significantly higher than that of the manual lesion counting } \\
\text { (C index, } 0.60)(\mathrm{P}=.03) \text {. In a multivariable survival model, } \\
\text { a higher aBSI remained independently associated with OS } \\
\text { (HR, } 1.06 ; 95 \% \mathrm{CI}, 1.01-1.11 ; \mathrm{P}=.03) \text {. A higher aBSI was } \\
\text { also independently associated with time to symptomatic } \\
\text { progression (HR, } 1.18 ; 95 \% \mathrm{CI}, 1.13-1.23 ; \mathrm{P}<.001) \text { and } \\
\text { time to opiate use for cancer pain }(\mathrm{HR}, 1.21 ; 95 \% \mathrm{CI} \text {, } \\
1.14-1.30 ; \mathrm{P}<.001) \text {. }\end{array}$ \\
\hline $\begin{array}{l}\text { Anand A, Morris } \\
\text { MJ, Larson SM, } \\
\text { Minarik D, } \\
\text { Josefsson A, } \\
\text { Helgstrand JT, et } \\
\text { al. (2016) }\end{array}$ & \begin{tabular}{|l|} 
Automated Bone \\
Scan Index as a \\
quantitative \\
imaging biomarker \\
in metastatic \\
castration-resistant \\
prostate cancer \\
patients being \\
treated with \\
enzalutamide. \\
\end{tabular} & $\begin{array}{l}\text { In the present } \\
\text { study, we } \\
\text { retrospectively } \\
\text { evaluated the } \\
\text { discriminatory } \\
\text { strength of the } \\
\text { automated BSI in } \\
\text { predicting overall } \\
\text { survival (OS) in } \\
\text { mCRPC patients } \\
\text { being treated with } \\
\text { enzalutamide. }\end{array}$ & $\begin{array}{l}\text { Retrospectively, we included patients who received } \\
\text { enzalutamide as a clinically approved therapy for } \\
\text { mCRPC and had undergone bone scan prior to } \\
\text { starting therapy. Automated BSI, prostate-specific } \\
\text { antigen (PSA), hemoglobin (HgB), and alkaline } \\
\text { phosphatase (ALP) were obtained at baseline. Change } \\
\text { in automated BSI and PSA were obtained from } \\
\text { patients who have had bone scan at week } 12 \text { of } \\
\text { treatment follow-up. Automated BSI was obtained } \\
\text { using the analytically validated EXINI BoneBSI } \\
\text { version 2. Kendall's tau ( } \tau \text { ) was used to assess the } \\
\text { correlation of BSI with other blood-based } \\
\text { biomarkers. Concordance index (C-index) was used } \\
\text { to evaluate the discriminating strength of automated } \\
\text { BSI in predicting OS. }\end{array}$ & $\begin{array}{l}\text { Eighty mCRPC patients with baseline bone scans were } \\
\text { included in the study. There was a weak correlation of } \\
\text { automated BSI with PSA ( } \tau=0.30) \text {, with } \mathrm{HgB}(\tau=-0.17) \text {, } \\
\text { and with ALP }(\tau=0.56) \text {. At baseline, the automated BSI } \\
\text { was observed to be predictive of OS (C-index } 0.72 \text {, } \\
\text { standard error (SE) } 0.03 \text { ). Adding automated BSI to the } \\
\text { blood-based model significantly improved the C-index } \\
\text { from } 0.67 \text { to } 0.72, \mathrm{p}=0.017 \text {. Treatment follow-up bone } \\
\text { scans were available from } 62 \text { patients. Both change in BSI } \\
\text { and percent change in PSA were predictive of OS. } \\
\text { However, the combined predictive model of percent PSA } \\
\text { change and change in automated BSI (C-index } 0.77) \text { was } \\
\text { significantly higher than that of percent PSA change alone } \\
\text { (C-index } 0.73), \mathrm{p}=0.041 .\end{array}$ \\
\hline \begin{tabular}{|l|} 
Miyoshi Y, \\
Yoneyama S, \\
Kawahara T, \\
Hattori Y, \\
Teranishi J, Kondo \\
K, et al. (2016)
\end{tabular} & $\begin{array}{l}\text { Prognostic value of } \\
\text { the bone scan } \\
\text { index using a } \\
\text { computer-aided } \\
\text { diagnosis system } \\
\text { for bone scans in } \\
\text { hormone-naive } \\
\text { prostate cancer } \\
\text { patients with bone } \\
\text { metastases. [46] }\end{array}$ & $\begin{array}{l}\text { This study aimed to } \\
\text { evaluate the } \\
\text { pretreatment BSI } \\
\text { as a prognostic } \\
\text { factor in hormone- } \\
\text { naive prostate } \\
\text { cancer patients } \\
\text { with bone } \\
\text { metastases. }\end{array}$ & $\begin{array}{l}\text { The study included } 60 \text { patients with hormone-naive, } \\
\text { bone metastatic prostate cancer that was initially } \\
\text { treated with combined androgen blockade therapy. } \\
\text { The BONENAVI system was used for calculating } \\
\text { the BSI. We evaluated the correlation between overall } \\
\text { survival (OS) and pretreatment clinicopathological } \\
\text { characteristics, including patients' age, initial prostate- } \\
\text { specific antigen (PSA) value, Gleason scores, clinical } \\
\text { TNM stage, and the BSI. Cox proportional hazards } \\
\text { regression models were used for statistical analysis. }\end{array}$ & $\begin{array}{l}\text { The median follow-up duration was } 21.4 \text { months. Clinical } \\
\text { or PSA progression occurred in } 37(61.7 \%) \text { patients and } 18 \\
(30.0 \%) \text { received docetaxel. Death occurred in } 16(26.7 \%) \\
\text { patients. Of these deaths, } 15(25.0 \%) \text { were due to prostate } \\
\text { cancer. The median OS was not reached. In multivariate } \\
\text { analysis, age and the BSI were independent prognostic } \\
\text { factors for OS. We evaluated the discriminatory ability of } \\
\text { our models, including or excluding BSI by quantifying the } \\
\text { C-index. The BSI improved the C-index from } 0.751 \text { to } \\
0.801 \text { for OS. Median OS was not reached in patients with } \\
\text { a BSI } \leq 1.9 \text { and median OS was } 34.8 \text { months in patients } \\
\text { with a BSI }>1.9(\mathrm{p}=0.039) \text {. }\end{array}$ \\
\hline $\begin{array}{l}\text { Mads H. P; Janne } \\
\text { R; Lars E; Poul F. } \\
\text { Høilund-Carlsen, } \\
\text { Oke G; Allan J; } \\
\text { Lars L. (2016) }\end{array}$ & \begin{tabular}{|l|} 
Bone Scan Index \\
predicts outcome \\
in patients with \\
metastatic \\
hormone-sensitive \\
prostate cancer. \\
{$[47]$}
\end{tabular} & \begin{tabular}{|l|} 
To evaluate the \\
Bone Scan Index \\
(BSI) for prediction \\
of castration \\
resistance and \\
prostate cancer- \\
specific survival \\
(PCSS).
\end{tabular} & $\begin{array}{l}\text { In all, } 88 \text { patients with prostate cancer awaiting } \\
\text { initiation of androgen-deprivation therapy due to } \\
\text { metastases were included. WBS was performed using } \\
\text { a two-headed c-camera. BSI was obtained using the } \\
\text { automated platform EXINI bone (EXINI } \\
\text { Diagnostics AB, Lund, Sweden). In Cox proportional } \\
\text { hazard models, time to castration-resistant prostate } \\
\text { cancer (CRPC) and PCSS were modelled as the } \\
\text { dependent variables, whereas prostate-specific } \\
\text { antigen (PSA) level, Gleason score and BSI were used } \\
\text { as explanatory factors. For Kaplan-Meier estimates, } \\
\text { BSI groups were dichotomously split into: BSI < } 1 \\
\text { and BSI } \geq 1 \text {. Discrimination between prognostic } \\
\text { models was explored using the concordance index } \\
\text { (C-index). }\end{array}$ & $\begin{array}{l}\text { The mean (range) age of the patients was } 72(52-92) \text { years, } \\
\text { the median (range) PSA level was } 73(4-5740) \text { ng/mL, the } \\
\text { mean (range) Gleason score was } 7.7(2-10) \text {, and the mean } \\
\text { (range) BSI was } 1.0(0-9.2) \text {. During a mean (range) follow- } \\
\text { up of } 26(8-49) \text { months, } 48 \text { patients became castration } \\
\text { resistant and } 15 \text { had died; most (13) from prostate cancer. } \\
\text { In multivariate analysis including PSA level, Gleason score } \\
\text { and BSI, only prediction by BSI was statistically } \\
\text { significant. This was true both for time to CRPC (hazard } \\
\text { ratio [HR] 1.45, } 95 \% \text { confidence interval [CI] } 1.22-1.74 \text {; } \\
\text { C-index increase from } 0.49 \text { to } 0.69) \text { and for PCSS (HR } \\
1.34,95 \% \text { CI 1.07-1.67; C-index increase from } 0.76 \text { to } \\
0.95) \text {. }\end{array}$ \\
\hline $\begin{array}{l}\text { Mariana R; Mattias } \\
\text { O; Reza K; Aseem } \\
\text { A; Ingela Franck- } \\
\text { Lissbrant, Jan-Erik } \\
\text { D; Anders W; } \\
\text { Camilla } \\
\text { Thellenberg- } \\
\text { Karlsson, Lars B; } \\
\text { Thomas St; Till E; } \\
\text { Per W; Lars E; Elin } \\
\text { T; Anders B. } \\
\text { (2016) }\end{array}$ & $\begin{array}{l}\text { Bone Scan Index as } \\
\text { an Imaging } \\
\text { Biomarker in } \\
\text { Metastatic } \\
\text { Castration-resistant } \\
\text { Prostate Cancer: A } \\
\text { Multicentre Study } \\
\text { Based on Patients } \\
\text { Treated with } \\
\text { Abiraterone } \\
\text { Acetate (Zytiga) in } \\
\text { Clinical Practice } \\
\text { [48] }\end{array}$ & \begin{tabular}{|l|} 
To evaluate the \\
value of BSI as a \\
biomarker for \\
outcome evaluation \\
in mCRPC patients \\
on treatment with \\
AA according to \\
clinical routine.
\end{tabular} & $\begin{array}{l}\text { We retrospectively studied } 104 \text { mCRPC patients who } \\
\text { received AA following disease progression after } \\
\text { chemotherapy. All patients underwent whole-body } \\
\text { bone scintigraphy before and during AA treatment. } \\
\text { Baseline and follow-up BSI data were obtained using } \\
\text { EXINI BoneBSI software (EXINI Diagnostics AB, } \\
\text { Lund, Sweden) }\end{array}$ & $\begin{array}{l}\text { Patients with an increase in BSI at follow-up of at most } \\
0.30(\mathrm{n}=54) \text { had a significantly longer median survival } \\
\text { time than those with an increase of BSI }>0.30(\mathrm{n}=50) \\
\text { (median: } 16 \text { vs } 10 \mathrm{mo} ; \mathrm{p}=0.001) \text {. BSI change was also } \\
\text { associated with OS in a multivariate Cox analysis including } \\
\text { commonly used clinical parameters for prognosis (Cindex } \\
=0.7 ; \text { hazard ratio: } 1.1 ; \mathrm{p}=0.03) \text {. The retrospective design } \\
\text { was a limitation. }\end{array}$ \\
\hline
\end{tabular}




\section{Discussion}

Automated bone scan index has a solid foundation to be a gold standard in standard imaging modality, with the potential to build on the current bone scan assessment at the baseline eligibility and aftertreatment monitoring. It both provides a quantitative measure of the percentage of the bone metastases involvement in the adult skeleton and has the potential to predict therapeutic effects and survival of patients with prostate cancer as a new imaging biomarker, as well as showing to be beneficial in clinical evaluation for optimising treatment and patient counselling. Bone scintigraphic assessment using BSI is becoming increasingly standardized, and it enables acquiring more objective data for the treatment and prognosis of the patient.

\section{Conclusions}

Bone scan index estimation is based on the known proportional weights of each of the 158 bones, and calculated as a sum of the fractional contribution of each bone expressed as a percentage of the entire skeleton. As a new imaging biomarker, bone scan index has potential to predict therapeutic effects and survival of patients with prostate cancer.

\section{References}

1. Wood TJ, Racano A, Yeung H, Farrokhyar F, Ghert M, Deheshi BM. Surgical management of bone metastases: quality of evidence and systematic review. Ann Surg Oncol. 2014. doi: 10.1245/ s10434-0144002-1.

2. Hung $M$, Stuart $A$, Cheng $C$, Hon SD, Spiker R, Lawrence B, Neese A, Brodke DS. Predicting the DRAM mZDI using the PROMIS anxiety and depression. Spine (Phila Pa 1976). 2015;40(3):179-83.

3. Landis SH, Murray T, Bolden S, Wingo PA. Cancer statistics. CA Cancer J Clin 1999; 49:8-29.

4. Robson M, Dawson N. How is androgen dependent metastatic prostate cancer best treated? Hematol Oncol Clin North Am 1996; 10:727-47.

24 5. Eisenberger M, Crawford E, Wolf M. Prognostic factors in stage D2 prostate cancer: important implications for future trials. Semin Oncol 1994;21:613-9.

6. Matzkin H, Perito P, Soloway M. Prognostic factors in metastatic prostate cancer. Cancer 1993; 72:3788-92.
7. Department of Urology and Renal Transplantation, Yokohama City University Medical Center, 4-57 Urafune-cho, Minamiku, Yokohama 232-0024, Japan.

8. Jacobs SC. Spread of prostatic cancer to bone. Urology, 1983; 21:337-44.

9. Crawford E, Eisenberger M, McLeod K. A controlled trial of leuprolide with and without flutamide in prostatic carcinoma. $N$ Engl J Med 1989;321:419-24.

10. Soloway M, Hardeman S, Hickey D. Stratification of patients with metastatic prostate cancer based on extent of disease on initial bone scan. Cancer 1988; 61:195202.

11. Heidenreich A, Aus G, Bolla M et al. EAU guidelines on prostate cancer. Eur Urol 2008; $53: 68-80$.

12. Rigaud J , Tiguert R, Le Normand L et al . Prognostic value of bone scan in patients with metastatic prostate cancer treated initially with androgen deprivation therapy . J Urol $2002 ; 168: 1423-6$.

13. Mitsui $\mathrm{Y}$; Shiina $\mathrm{H}$; Yamamoto $\mathrm{Y}$; Haramoto M; Arichi N; Yasumoto $\mathrm{H}$; Kitagaki H; Igawa M. Prediction of survival benefit using an automated bone scan index in patients with castration-resistant prostate cancer. 2012; In BJU international 110 : 62834.

14. Joniau S, Briganti A, Gontero P, et al. European Multicenter Prostate Cancer Clinical and Translational Research Group (EMPaCT). Stratification of high-risk prostate cancer into prognostic categories: a European multi-institutional study. Eur Urol 2015;67:157-64.

15. Thoreson GR, Gayed BA, Chung PH, Raj GV. Emerging therapies in castration resistant prostate cancer. Can J Urol 2014;21(Suppl 1):98-105.

16. Kirby M, Hirst C, Crawford ED. Characterising the castration-resistant prostate cancer population: a systematic review. Int J Clin Pract 2011;65:1180-92.

17. Gillessen S, Omlin A, Attard G, et al. Management of patients with advanced prostate cancer: recommendations of the $\mathrm{St}$ Gallen Advanced Prostate Cancer Consensus Conference (APCCC) 2015. Ann Oncol 2015;26:1589-604. 
18. Merseburger AS, Bellmunt J, Jenkins C, Parker C, Fitzpatrick JM, European Treatment Practices Group. Perspectives on treatment of metastatic castration-resistant prostate cancer. Oncologist 2013;18:55867.

19. Fizazi K, Massard C, Smith M, et al. Bonerelated parameters are the main prognostic factors for overall survival in men with bone metastases from castration-resistant prostate cancer. Eur Urol 2015;68:42-50.

20. Sadik M, Suurkula M, Ho“glund P, Ja“rund A, Edenbrandt LJ. Improved classifications of planar whole-body bone scans using a computerassisted diagnosis system: a multicenter, multiple-reader, multiple-case study. Nucl Med 2009;50:368-75.

21. Bubendorf L, Scho“pfer A, Wagner U, Sauter G, Moch H, Willi N, et al. Metastatic patterns of prostate cancer: an autopsy study of 1,589 patients. Hum Pathol. 2000;31:578-83.

22. Wakabayashi H; Nakajima K; Mizokami A; Namiki M; Inaki A; Taki J; Kinuya S. Bone scintigraphy as a new imaging biomarker: the relationship between bone scan index and bone metabolic markers in prostate cancer patients with bone metastases. 2013. 9:902-907.

23. Knudson G, Grinis G, Lopez-Majano V, Sansi P, Targonski P, Rubenstein M, et al. Bone scan as a stratification variable in advanced prostate cancer. Cancer. 1991;68:316-20.

24. Amico S, Liehn JC, Desoize B, Larbre H, Deltour G, Valeyre J. Comparison of phosphatase isoenzymes PAP and PSA with bone scan in prostate carcinoma. J Clin Nucl Med. 1991;13:643-8.

25. Soloway MS, Hardeman SW, Hickey D, Raymond J, Todd B, Soloway S, et al. Stratification of patients with metastatic prostate cancer based on extent of disease on initial bone scan. Cancer. 1988;61:195202.

26. Soloway MS, Hardeman SW, Hickey D, Raymond J, Todd B, Soloway S, et al. Stratification of patients with metastatic prostate cancer based on extent of disease on initial bone scan. Cancer. 1988;61:195202.
27. Zafeirakis AG, Papatheodorou GA, Limouris GS. Clinical and imaging correlations of bone turnover markers in prostate cancer patients with bone only metastases. Nucl Med Commun. 2010;31: 249-53.

28. Soloway MS, Hardeman SW, Hickey D, Raymond J, Todd B, Soloway S, Moinuddin M: Stratification of patients with metastatic prostate cancer based on extent of disease on initial bone scan. Cancer 1988, 61:195202.

29. Noguchi M, Kikuchi H, Ishibashi M, Noda $\mathrm{S}$ : Percentage of the positive area of bone metastasis is an independent predictor of disease death in advanced prostate cancer. $\mathrm{Br} J$ Cancer 2003, 88:195-201. doi:10.1038/sj.bjc.6600715.

30. Erdi YE, Humm JL, Imbriaco M, Yeung H, Larson SM: Quantitative bone metastases analysis based on image segmentation. JNucl Med 1997, 38:1401-1406.

31. Sabbatini P, Larson SM, Kremer A, Zhang ZF, Sun M, Yeung H, Imbriaco M, Horak I, Conolly M, Ding C, Ouyang P, Kelly WK, Scher HI: Prognostic significance of extent of disease in bone in patients with androgen-independent prostate cancer. JClinOncol 1999, 17:948-957.

32. Sadik M, Suurküla M, Höglund P, Jarund A, Edenbrandt L: Quality of planar wholebody bone scan interpretations - a nationwide survey. Eur J Nucl MedMol Imaging 2008, 35:1464-1472. doi:10.1007/s00259-008-0721-5.

33. Kaboteh R, Gjertsson P, Leek Hk, Lomsky M, Ohlsson M, Sjöstrand K, Edenbrandt L: Progression of bone metastases in patients with prostate cancer - automated detection of new lesions and calculation of bone scan index. EJNMMI Res 2013, 3(1):64. doi:10.1186/2191-219X-3-64.

34. Ulmert D, Kaboteh R, Fox JJ, Savage C, Evans MJ, Lilja H, Abrahamsson P-A, Björk T, Gerdtsson A, Bjartell A, Gjertsson P, Höglund P, Lomsky M, Ohlsson M, Richter J, Sadik M, Morris MJ, Scher HI, Sjöstrand K, Yu A, Suurküla M, Edenbrandt L, Larson SM: A novel automated platform for quantifying the extent of skeletal tumour involvement in prostate cancer patients 
using the bone scan index. EurUrol 2012, 62(1):78-84.

doi:10.1016/j.eururo.2012.01.037.

35. Mitsui $Y$, Shiina $H$, Yamamoto $Y$, Haramoto M, Arichi $\mathrm{N}$, Yasumoto $\mathrm{H}$, Kitagaki H, Igawa M: Prediction of survival benefit using an automated bone scan index in patients with castration-resistant prostate cancer. BJU Int 2012, 110:628-34. doi:10.1111/j.1464-410X.2012.11355.x.

36. Erdi YE, Humm JL, Imbriaco M, Yeung $H$, Larson SM: Quantitative bone metastases analysis based on image segmentation. J Nucl Med 1997, 38:1401-1406.

37. Sabbatini P, Larson SM, Kremer A, et al. (1999) Prognostic significance of extent of disease in bone in patients with androgenindependent prostate cancer. J Clin Oncol 17:948-957.

38. Yohara J, Noguchi M, Noda S (2003) Quantitative evaluation of bone metastases in patients with advanced prostate cancer during systemic treatment. BJU Int 92:379_ 383.

39. Citrin DL, Hougen C, Zweibel W, et al. (1981) The use of serial bone scans in assessing response of bone metastases to systemic treatment. Cancer 47:680-685.

40. Dennis ER, Jia X, Mezheritskiy IS, Stephenson RD, Schoder H, Fox JJ, Heller G, Scher HI, Larson SM, Morris MJ: Bone scan index: a quantitative treatment response biomarker for castration-resistant metastatic prostate cancer. J Clin Oncol 2012, 30:519-524.

41. Reza K, Peter G, Håkan L, Milan L1, Mattias O, Karl S, Lars E; Progression of bone metastases in patients with prostate cancer - automated detection of new lesions and calculation of bone scan index. 2013, 3:64.

42. Ulmert D, Kaboteh R, Fox JJ, Savage C, Evans MJ, Lilja H, Abrahamsson P-A, Björk T, Gerdtsson A, Bjartell A: A novel automated platform for quantifying the extent of skeletal tumour involvement in prostate cancer patients using the bone scan index. Eur Urol 2012, 62:78-84.

43. Snyder W: Report of the Task Group on Reference Man: A Report/ Prepared by a Task Group of Committee 2 of the International Commission on Radiological Protection. Oxford: Pergamon; 1975.

44. Andrew J. A; Aseem A; Lars E; Eva B; Anders B; Anders W; Cora N. S; Roberto P; Helen T; Örjan N; Michael A. C; Michael J. M. Phase 3 Assessment of the Automated Bone Scan Index as a Prognostic Imaging Biomarker of Overall Survival in Men With Metastatic Castration-Resistant Prostate Cancer A Secondary Analysis of a Randomized Clinical Trial 2018, 4 (7):944951.

45. Anand A, Morris MJ, Larson SM, Minarik D, Josefsson A, Helgstrand JT, et al. Automated Bone Scan Index as a quantitative imaging biomarker in metastatic castration-resistant prostate cancer patients being treated with enzalutamide. 2016, 6:23.

46. Miyoshi Y, Yoneyama S, Kawahara T, Hattori Y, Teranishi J, Kondo K, et al. Prognostic value of the bone scan index using a computer-aided diagnosis system for bone scans in hormone-naive prostate cancer patients with bone metastases. (2016), 16:128.

47. Mads H. P; Janne R; Lars E; Poul F. Høilund-Carlsen, Oke G; Allan J; Lars L. Bone Scan Index predicts outcome in patients with metastatic hormone-sensitive prostate cancer. 2016; 117: 748-75

48. Reza M, Ohlsson M, Kaboteh R, et al. Bone Scan Index as an imaging biomarker in metastatic castration-resistant prostate cancer: a multicentre study based on patients treated with abiraterone acetate (Zytiga) in clinical practice. Eur Urol Focus. 